\title{
Model of Sustainable Electrical Power Management: Lamp Efficacy of the National Street Lighting in North Sumatera Province
}

Model of Sustainable Electrical Power

\author{
Janter Napitupulu
}

Study Program of Natural Resources Management and Environment, Postgraduate School, University of Sumatera Utara, Sumatera, Indonesia Faculty of Engineering, University of Darma Agung, Medan, Indonesia

Herman Mawengkang

Faculty of Mathematics and Natural Sciences, University of Sumatera Utara, Sumatera, Indonesia

Usman Ba'afai

Faculty of Engineering, University of Sumatera Utara, Sumatera, Indonesia

Nasruddin M.N.

Faculty of Mathematics and Natural Sciences, University of Sumatera Utara, Sumatera, Indonesia

\begin{abstract}
Purpose - The purpose of this study was to determine the efficacy value of national street lighting on energy conservation and carbon dioxide $\left(\mathrm{CO}_{2}\right)$ emission reduction.

Design/Methodology/Approach - The methods used are the measurement of electrical parameters (low voltage network), the national road illumination level with SON lamp specification, $400 \mathrm{~W}, 180 \mathrm{~W}$, and $110 \mathrm{Lumen} / \mathrm{W}$, the simulation of energy conservation calculation, and the $\mathrm{CO}_{2}$ emission reduction obtained by utilizing panel solar cells as a source of energy and LED lights for illumination.

Finding - The results show the efficacy of a 100-W light bulb at an altitude of $8 \mathrm{~m}$ for the following specification of light bulbs: LED, 130 Lumens/W, SON, 110 Lumen/W, and MBF, 53 Lumen/W gives the illumination level respectively 13,913 Lux, 11,773 Lux, and 5,672 Lux. By replacing the $180 \mathrm{~W}$ SON lamp with an LED, $100 \mathrm{~W}$, of energy conservation by $3.171 \mathrm{GW} h$ is obtained, which is equivalent to a $\mathrm{CO}_{2}$ emission reduction of $3.641 \mathrm{kTon} \mathrm{CO}_{2}$.
\end{abstract}

(C) Janter Napitupulu, Herman Mawengkang, Usman Ba'afai, Nasruddin M.N. Published in the Emerald Reach Proceedings Series. Published by Emerald Publishing Limited. This article is published under the Creative Commons Attribution (CC BY 4.0) licence. Anyone may reproduce, distribute, translate and create derivative works of this article (for both commercial and noncommercial purposes), subject to full attribution to the original publication and authors. The full terms of this licence may be seen at http://creativecommons.org/licences/by/4.0/legalcode

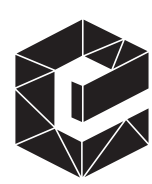

Emerald Reach Proceedings Series Vol. 1 Emerald Publishing Limited DOI $10.1108 / 978-1-78756-793-1-00097$ 
Proceedings of MICoMS 2017

Originality/Value - This study is a continuation of a study of energy conservation with the utilization of solar cells as an electrical power source for an LED bulb that replaces low-voltage networks as a power source for the bulb type SON.

Keywords Electric power, energy conservation, solar cell, sunlight, light lamp

All papers within this proceedings volume have been peer reviewed by the scientific committee of the 610 Malikussaleh International Conference on Multidisciplinary Studies (MICoMS 2017).

\section{Introduction}

The provision of electrical energy for sectoral uses is generated using fossil-fueled natural resources such as oil and coal. Its use continues to increase, while the number of natural resources is limited.

In future, the lack of electrical energy can occur since the supply of electrical energy is limited when compared to the actual energy needs. In urban areas, the predicted rate of growth in electricity demand will tend to increase which, if not resolved, can cause the level of electricity supply to be disrupted.

For this purpose, the management of electrical energy considers conservation of energy as a solution that can be achieved with the consumption or supply of less energy but gives the same effect of lighting and illumination (Mohamed et al., 2009). The energy conservation can be applied to industrial room lighting. The energy conservation can be obtained through solar cells as a source of energy illumination in buildings (Dhingra et al., 2009).

To overcome the limitation of electric energy at night, especially for street lighting, energy from solar cell was utilized as energy source instead of LED lamps (Padmini, 2014).

Conservation efforts can be achieved through two aspects: (1) Aspect of technology and (2) aspect of human behavior change. In street lighting, electronic ballasts consume less energy than electromagnetic ballasts that can save energy up to $18 \%$ (Escolar et al., 2015). In the case of electric energy crisis, Bangladesh is one of the developing countries that saved electricity consumption from 3\% to $20 \%$ through changes in human behavior (Khan et al., 2016).

There are two reasons for the usage of solar cells, namely, (1) limited fuel supplies used for electric power generation and (2) environmental hazards caused by the disposal of waste products during the conversion process.

\section{Materials and methods}

\subsection{Material}

The measurement of the electrical quantities was performed using the following multitester measuring instruments: Heles YX-360 TRNB Reg.271-488, voltmeter, ammeter: Digital Multimeter CD772 Sanwa, tangmeter: Clampmeter 8 model 3908 VIP Electrical Instruments Works, Ltd., and luxmeter: Digital Luxmeter 1010 specification with a measurement range of $0.1-100 \times 500$ Lux.

\subsection{Methods}

2.2.1. Carbon dioxide emission factor The environmental hazard can be measured from the value of carbon dioxide $\left(\mathrm{CO}_{2}\right)$ emission and determined by $\mathrm{CO}_{2}$ emission factor determined as $1.14 \mathrm{~kg} \mathrm{CO} / \mathrm{kW} \mathrm{h}$. Emission factor becomes the basis in the process of environmental pollution. Power generation with fossil fuels is a major source of greenhouse gas emissions, especially $\mathrm{CO}_{2}$ gas. One way to reduce $\mathrm{CO}_{2}$ in the air is to use a power plant that has a low $\mathrm{CO}_{2}$ emission factor. $\mathrm{CO}_{2}$ emission factor can be determined by using the following formula: 
$\mathrm{CO}_{2}$ emission factor $=\mathrm{CO}_{2}$ emissions/energy generated, where, $\mathrm{CO}_{2}$ emissions $=$ fuel consumption $\times \%$ C fuel $\times 44 / 12$.

The emission time series model can be used to determine the accumulation of $\mathrm{CO}_{2}$ concentration (Boykoff et al., 2010).

2.2.2. Sunlight and solar cells Light is an electromagnetic wave that under certain conditions can behave like a particle. Electromagnetic waves are waves that do not require a medium to propagate, hence light can propagate without a medium. Therefore, sunlight can reach the earth and energize lives in it. Light travels very fast with a speed of $3 \times 10^{8} \mathrm{~m} / \mathrm{s}$, meaning that within a second light can travel a distance of $300,000,000 \mathrm{~m}$ or $300,000 \mathrm{~km}$, and has a radiation of $1,373 \mathrm{~W} / \mathrm{m}^{2}$ with $1-2 \%$ error. The source of light that is included in the natural light is the sun. Sunlight has a spectrum which can be seen from the division of energy regions comprising $8 \%$ in the ultra violet region, $44 \%$ in the visible region, and $48 \%$ in the infra red region. Light has a constant known as a solar constant (Io) with a value of Io $=1.37 \pm 0.02 \mathrm{~kW} / \mathrm{m}^{2}$ (Mc.Veigh, 1983).

Theoretically, the potential of solar resources is the average solar energy on the earth's surface expressed in $\mathrm{kW} \mathrm{h} / \mathrm{m}^{2} /$ year, which is the kilowatt hour on every square meter in the horizontal plane measured every day, month or year, and Bulgaria is a country in Europe which is divided into three solar regions 0 .

Indonesia, which is a tropical region, has the potential of solar energy where the average daily insolation is $4.5-4.8 \mathrm{~kW} \mathrm{~h} / \mathrm{m}^{2} /$ day.

Solar cells convert solar radiation in $\mathrm{kW} \mathrm{h} / \mathrm{m}^{2} /$ day into electric power as follows:

$$
P=\operatorname{Ir} . A
$$

where $I r$ is the intensity of solar radiation and $A$ is wide of solar cells $\left(\mathrm{m}^{2}\right)$.

Sunlight on the surface of the earth is capable of providing power of $1,000 \mathrm{~W} / \mathrm{m}^{2}$ in bright weather, which in turn will produce current of about $30 \mathrm{~mA} / \mathrm{cm}^{2}$.

If the solar cell module has an area of $1 \mathrm{~m}^{2}$ with an efficiency of $10 \%$, it is capable of generating $100 \mathrm{~W}$ electricity. The solar cell module can generate electricity depending on the level of sun exposure. The greater the level of sunlight exposure, the greater the electrical power that the solar cell modules can generate.

2.2.3. Light efficacy The efficacy of light is the ratio of the lumen output to the power consumption expressed in Lumen/W units.

$$
K=\phi / P
$$

where $K$ is the light efficacy $(\mathrm{Lm} / \mathrm{W}), \phi$ is flux light $(\mathrm{Lm})$, and $P$ is the electric power $(\mathrm{W})$.

In street lighting, the height of the lamppost affects the spreading of light. The higher the pole is the wider the resulting light will be with a smaller level of illumination.

The angle of the tilt, the line connecting the endpoint of the lamp and the point in the middle of the path with a horizontal line as seen in Figure 1, can be determined using the following equation:

$$
\begin{array}{ll}
r & =\sqrt{h^{2}+c^{2}} \\
\operatorname{Cos} \psi & =h / r
\end{array}
$$

where $r$ is the side of beveled line, the distance from the end of the lamp to the point in the middle of the road; $c$ is the horizontal line, the distance from the projection point of the 
Proceedings of

MICoMS 2017

\section{2}

Figure 1.

Effect of lamppost

height on

illumination

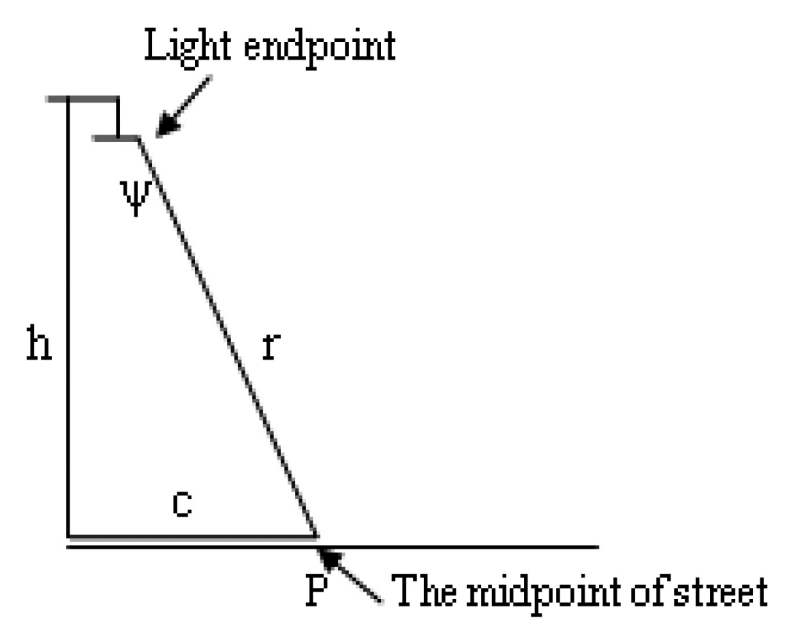

lamp end to the point in the middle of the road; $h$ is the pole height; and $\psi$ is the angle between $r$ and $c$.

The intensity of light $(I)$ in units of candela (cd) can be determined using the following equation:

$$
\begin{gathered}
I=\phi / \omega \\
\omega=4 \pi \\
K=\phi / P \text { or } \phi=K \times P
\end{gathered}
$$

Then,

$$
I=K \times P / 4 \pi
$$

Illumination $E_{\mathrm{P}}$ in units of Lux at the point $P$ in the middle of the street is

$$
E_{p}=I \times \operatorname{Cos} \psi / r^{2}
$$

2.2.4. Conservation approach model $\mathrm{P}_{P J U N-S S} P_{\mathrm{PJUN}-\mathrm{SS}}$ is a model approach with the utilization of solar cells as a source of energy for LED light in national street lighting. Energy conservation can be obtained as follows:

$$
\begin{aligned}
P_{\text {PJUN-SS }} & =P_{\text {PJUN-LED }} \\
P_{\text {Konsv-SS }} & =\left(P_{\mathrm{SUTR}-\mathrm{SON}}-P_{\mathrm{PJUN}-\mathrm{SS}}\right) \times n \\
W_{\text {Konsv-SS }} & =P_{\text {Konsv-SS }} \times \mathrm{O} \\
J_{\text {Konsv-SS }} & =W_{\text {Konsv-SS }} \times J_{\mathrm{E}}
\end{aligned}
$$

where

$J_{\text {Konsv-SS }}$ : energy conservation is converted to $\mathrm{CO}_{2}$ emission $(\mathrm{kg})$

$E_{\text {Konsv-SS }}$ : annual energy conservation ( $\mathrm{kW} \mathrm{h} /$ year)

$P_{\text {Konsv-SS }}:$ conservation of electric power $(\mathrm{kW})$

$P_{\text {PJUN-SON }}$ : the growing needs of electrical power for the lamp $\mathrm{P}_{J U N-S O N}$

$P_{\text {PJUN-LED }}:$ power light for $\mathrm{P}_{J U N-L E D}$ 
n : number of light

Oh : operational hours

$J_{\mathrm{E}} \quad: \mathrm{CO}_{2}$ emission factor $(\mathrm{kg} / \mathrm{kW} \mathrm{h})$.

$F k=$ multiflier factor due to losses and efficiency

$\mathrm{LPM}=$ duration of solar radiation

Energy generation $\left(W_{\mathrm{SS}}\right)=\operatorname{load} P_{\mathrm{PJU}-\mathrm{LED}}$

(Watt) $\times$ time (hour)

Solar cell module capacity $\left(P_{\mathrm{SS}}\right)=\left(W_{\mathrm{sS}} \times \mathrm{Fk}\right) / \mathrm{LPM}$.

\section{Results and discussion}

\subsection{The Effect of Height Variation of Light Pole on Illumination}

The effect of the height variation of light poles on the illumination produced with certain light efficacy on the primary arterial road at the midpoint of the road is obtained by the using the following calculation:

(1) Lamp type: SON, $400 \mathrm{~W}, 110$ lumens/W

Road width: $8 \mathrm{~m}$

$$
\begin{aligned}
h & =12 \mathrm{~m} \\
c & =2.95 \mathrm{~m} \\
r & =\sqrt{12^{2}+2.95^{2}} \\
\operatorname{Cos} \psi & =12.35 \mathrm{~m} \\
& =0.97 \\
I & =110 \times 400 /(4 \times 3.14) \\
& =3,503.18 \mathrm{~cd}
\end{aligned}
$$

Then,

$$
\begin{aligned}
E_{\mathrm{p}} & =3,503.18 \times 0.97 / 12.352 \\
& =22.27 \mathrm{Lux}
\end{aligned}
$$

(2) Lamp type: MBF, 400 W, 53 lumens/W

Road width: $8 \mathrm{~m}$

$$
\begin{aligned}
h & =12 \mathrm{~m} \\
c & =2.95 \mathrm{~m} \\
r & =\sqrt{12^{2}+2.95^{2}} \\
\operatorname{Cos} \psi & =12.35 \mathrm{~m} \\
& =0.97 \\
I & =53 \times 400 /(4 \times 3.14) \\
& =1.687 .89 \mathrm{~cd}
\end{aligned}
$$

Then,

$$
\begin{aligned}
E_{\mathrm{p}} & =1,687.89 \times 0.97 / 12.352 \\
& =10.73 \mathrm{Lux}
\end{aligned}
$$


Proceedings of Height variation of lampposts against illumination with SON/MBF, $400 \mathrm{~W}$, generated at the MICoMS 2017 midpoint of the road width $8 \mathrm{~m}$ can be seen in Table 1 .

\section{SON/MBF Lamp Specifications:}

- For lamp types: SON, $180 \mathrm{~W}, 110$ lumens/W and MBF, $180 \mathrm{~W}, 53$ lumens/W, the effect of variations on lamp height to illumination is presented in Table 2.

614

- For lamp types: SON, $100 \mathrm{~W}, 110$ lumens/Wand MBF, $100 \mathrm{~W}, 53$ lumens/W, the effect of variations on lamp height to illumination is presented in Table 3.

LED Lighting Specifications:

- For lamp type: LED, $150 \mathrm{~W}, 130$ lumens/W, the effect of variations on lamp height to illumination is presented in Table 4.

- For lamp type: LED, $100 \mathrm{~W}, 130$ lumens/W, the effect of variations on lamp height to illumination is presented in Table 5.

Table 1.

Variation Height of lampposts against illumination SON/ MBF, 400 Watt generated at the midpoint of the road road width $8 \mathrm{~m}$

\begin{tabular}{lccc}
\hline & & \multicolumn{2}{c}{ Illumination (Lux) } \\
\cline { 3 - 4 } No. & Lamppost height $(\mathrm{m})$ & SON & MBF \\
\hline 1 & 10 & 30,65 & 15,31 \\
2 & 11 & 25,96 & 12,59 \\
3 & 12 & 22,27 & 10,73 \\
\hline
\end{tabular}

\section{Table 2.}

Variation Height of lampposts against illumination SON/ MBF, 180 Watt generated at the midpoint of the road, road width $7 \mathrm{~m}$

\begin{tabular}{lclc}
\hline & & \multicolumn{2}{c}{ Illumination (Lux) } \\
\cline { 3 - 4 } No. & Lamppost height $(\mathrm{m})$ & SON & MBF/U \\
\hline 1 & 7 & 26,49 & 12,769 \\
2 & 8 & 21,191 & 10,210 \\
3 & 9 & 18,711 & 8,308 \\
\hline
\end{tabular}

\section{Table 3.}

Variation Height of lampposts against illumination SON/ MBF, 100 Watt generated at the midpoint of the road, road width $7 \mathrm{~m}$

\begin{tabular}{lcrc}
\hline & & \multicolumn{2}{c}{ Illumination (Lux) } \\
\cline { 3 - 4 } No. & Lamppost height $(\mathrm{m})$ & $\mathrm{SON}$ & $\mathrm{MBF} / \mathrm{U}$ \\
\hline 1 & 7 & 14,718 & 7,488 \\
2 & 8 & 11,773 & 5,672 \\
3 & 9 & 9,580 & 4,615 \\
\hline
\end{tabular}


The electrical energy needs of the national road segment in 2019 are obtained by the following formulation:

(1) Load of SON on the length of primary arterial road:

The specified lighting quality of primary arterial road is 11-20 Lux. To obtain the lighting quality, SON lamp, $400 \mathrm{~W}$, is used with lamp height $11 \mathrm{~m}$, and distance between poles being $40 \mathrm{~m}$. Then, the electrical energy consumption of primary arterial road along 1,142 $\mathrm{km}$ with the operation time 4,145 $\mathrm{h}$ in 1 year is as follows:

(a) The number of pole PJU is (the length of the road/40) +1

(b) Electric power required on street lighting PJU

$$
\begin{aligned}
P_{\text {PJU-SUTR }} & =400 \mathrm{~W} \times \text { number of poles } \\
& =400 \mathrm{~W} \times 28,551 \\
& =11.240 \mathrm{MW}
\end{aligned}
$$

(c) Electrical energy needs of street lighting for the length of national primary arterial road segment are as follows:

$$
\begin{aligned}
W_{\text {PJU-SUTR }} & =400 \mathrm{~W} \times \text { number of poles } \times 4,145 \mathrm{~h} \\
& =400 \mathrm{~W} \times 28,551 \text { poles } \times 4,145 \mathrm{~h} \\
& =47.337 \mathrm{GWh}
\end{aligned}
$$

(2) Load of SON on the length of national primary collector road:

The specified lighting quality of primary collector road is 3-7 Lux. To obtain the lighting quality, SON lamp, $180 \mathrm{~W}$, is used with lamp height $8 \mathrm{~m}$, and distance between poles being $40 \mathrm{~m}$. Then, the electrical energy consumption of primary collector road along 1,490.22 $\mathrm{km}$ with the operation time 4,145 $\mathrm{h}$ in 1 year is as follows:

(a) The number of pole PJU is (the length of the road/40) +1

(b) Electric power required on street lighting PJU

\begin{tabular}{llll}
\hline & & \multicolumn{2}{c}{ Illumination (Lux) } \\
\cline { 3 - 4 } No. & Lamppost height $(\mathrm{m})$ & Road width-7m & Road width-8m \\
\hline 1 & 7 & 26,091 & 24,215 \\
2 & 8 & 20,870 & 19,660 \\
3 & 9 & 16,983 & 16,195 \\
\hline
\end{tabular}

Table 4.

\begin{tabular}{|c|c|c|c|c|}
\hline \multirow[b]{2}{*}{ No. } & \multirow[b]{2}{*}{ Lamppost height (m) } & \multicolumn{2}{|c|}{ Illumination (Lux) } & \multirow{2}{*}{$\begin{array}{c}\text { Variation Height of } \\
\text { lampposts against } \\
\text { illumination LED, }\end{array}$} \\
\hline & & Road width-7m & Road width-8m & \\
\hline 1 & 7 & 17,394 & 16,143 & $\begin{array}{l}\text { 100Watt generated at } \\
\text { the midpoint of the }\end{array}$ \\
\hline 2 & 8 & 13,913 & 13,106 & the midpoint of the \\
\hline 3 & 9 & 11,322 & 10,796 & road \\
\hline
\end{tabular}

Variation Height of lampposts against illumination LED, 150 Watt generated at the midpoint of the road 
Proceedings of

MICoMS 2017

\section{6}

$$
\begin{aligned}
P_{\mathrm{PJU}-\mathrm{SUT}} & =180 \mathrm{~W} \times \text { number of poles } \\
& =180 \mathrm{~W} \times 37,256 \\
& =6.706 \mathrm{MW}
\end{aligned}
$$

(c) Electrical energy needs of street lighting for the length of national primary collector road segment are as follows:

$$
\begin{aligned}
W_{\text {PJU-SUTR }} & =180 \mathrm{~W} \times \text { number of poles } \times 4,145 \mathrm{~h} \\
& =180 \mathrm{~W} \times 37,256 \text { poles } 4,145 \mathrm{~h} \\
& =15.442 \mathrm{GW} \mathrm{h}
\end{aligned}
$$

Thus, the total need of electrical energy for street lighting due to the increase in national roads is $15.442 \mathrm{GW}$.

\subsection{Potential use of solar cells}

The energy needs of national public road lighting in North Sumatera province can be analyzed from the value of electrical energy generated by each solar cell module and the overall need of solar cell panels required to replace the energy generated by conventional power generation.

By using these solar cell modules, the need of electrical energy for public road lighting on national roads in 2019 and its increase can be obtained as follows:

(1) Load of LED light on the total length of national road:

The specified lighting quality is 11-20 Lux. To obtain the lighting quality, LED lamp, $100 \mathrm{~W}$, is used with lamp height $7 \mathrm{~m}$, and distance between poles being $40 \mathrm{~m}$. Then, the electrical energy consumption of primary arterial road and primary collector road along 2,632.22 $\mathrm{km}$ with the operation time $4,145 \mathrm{~h}$ in 1 year is as follows:

(a) The number of pole PJU is (the length of the road/40) +1

(b) Electric power required on street lighting PJU

$$
\begin{aligned}
P_{\text {PJU-LED }} & =100 \mathrm{~W} \times \text { number of poles } \\
& =100 \mathrm{~W} \times 65,807 \\
& =6.580 \mathrm{MW}
\end{aligned}
$$

(c) Electrical energy needs of street lighting for the total length of national road segment are as follows:

$$
\begin{aligned}
W_{\text {PJU-LED }} & =100 \mathrm{~W} \times \text { number of poles } \times 4,145 \mathrm{~h} \\
& =100 \mathrm{~W} \times 65,807 \text { poles } \times 4,145 \mathrm{~h} \\
& =27.277 \mathrm{GWh}
\end{aligned}
$$

(2) Load of LED light due to the increase of national road segment:

The increase in the length of the national roads is around $382.56 \mathrm{~km}$. The electrical energy needs of street lighting along the length of national primary collector road segment are as follows

$$
\begin{aligned}
W_{\mathrm{PJU}-\mathrm{LED}} & =100 \mathrm{~W} \times \text { number of poles } \times 4,145 \mathrm{~h} \\
& =100 \mathrm{~W} \times 9,565 \text { poles } \times 4,145 \mathrm{~h} \\
& =3.964 \mathrm{GWh}
\end{aligned}
$$


Thus, the total need of electrical energy for street lighting due to the increase in national roads is $3.964 \mathrm{GW}$ h.

(3) Capacity of solar cell module:

Sunlight can generate electrical energy of $1,000 \mathrm{~W} / \mathrm{m}^{2}$ at peak times. The solar panel efficiency of $15 \%$ with an area of $1 \mathrm{~m}^{2}$ panel each, can produce output power of $150 \mathrm{Wp}$.

Solar cell module capacity to serve the load of national street lighting with PJU-LED, $100 \mathrm{~W}$, for $12 \mathrm{~h}, 18.00-6.00$, with 1.1 as multiplier factor, and $5.7 \mathrm{~h}$ as the duration of solar exposure, then

Load $P_{\text {PJU-LED }}=100 \mathrm{~W}$

The energy requirement to serve the load $P_{\mathrm{PJU}-\mathrm{LED}}=100 \mathrm{~W}$ is as follows:

$$
\begin{aligned}
\text { Energy generation }\left(W_{\mathrm{SS}}\right) & =100 \mathrm{~W} \times 12 \mathrm{~h} \\
& =1,200 \mathrm{Wh} \\
& =1.2 \mathrm{kWh}
\end{aligned}
$$

Solar cell modul capacity $\left(P_{\mathrm{SS}}\right)=(120 \mathrm{~W} \times 12 \mathrm{~h} \times 1.1) / 5.7 \mathrm{~h}$

$$
=277 \mathrm{Wp}
$$

Thus, the need for solar cell modules to meet PJU-LED, $100 \mathrm{~W}$, is two sets of solar cell modules each with a capacity of $130 \mathrm{Wp}$.

\subsection{Effect of efficacy on illumination}

Effect of height variation of lamppost on Illumination by using LED/SON/MBF can be seen in Table 6.

Light efficacy affects the energy consumption for the lamp. Hence, by using a high light efficacy lamp, maximum energy conservation is possible.

\subsection{Energy Conservation}

The growth of national roads in 2019 will be lengthy, around $382.56 \mathrm{~km}$. This needs the growth of electric power also to fulfill the demand of lighting the entire length of the national roads.

\begin{tabular}{|c|c|c|c|c|c|}
\hline \multirow[b]{4}{*}{ No. } & \multirow[b]{4}{*}{ Lamppost height (m) } & \multicolumn{3}{|c|}{ Illumination (Lux) } & \multirow{7}{*}{$\begin{array}{r}\text { Table } 6 . \\
\text { Effect of height } \\
\text { variation of lamppost } \\
\text { on Illumination LED/ } \\
\text { SON/MBF, } 100 \text { watts } \\
\text { directed at midpoint } \\
\text { of road, road width } \\
7 \mathrm{~m}\end{array}$} \\
\hline & & LED & SON & MBF & \\
\hline & & \multicolumn{3}{|c|}{ Efficacy (lumen/watt) } & \\
\hline & & 130 & 110 & 53 & \\
\hline 1 & 7 & 17,394 & 14,718 & 7,488 & \\
\hline 2 & 8 & 13,913 & 11,773 & 5,672 & \\
\hline 3 & 9 & 11,322 & 9,580 & 4,615 & \\
\hline
\end{tabular}

When the SON lamp, $180 \mathrm{~W}$, is changed to LED, $150 \mathrm{~W}$, having the value of the illumination close to the same, energy conservation of $30 \mathrm{~W}$ per light bulb will be obtained:

$$
\begin{aligned}
W_{\text {Konsv-SS }} & =30 \mathrm{~W} \times \text { number of poles } \times 4,145 \mathrm{~h} \\
& =30 \mathrm{~W} \times 9,565 \text { poles } \times 4,145 \mathrm{~h} \\
& =1.189 \mathrm{GWh}
\end{aligned}
$$


Proceedings of When the SON lamp, $180 \mathrm{~W}$, is changed to an LED, $100 \mathrm{~W}$, that has fulfilled the specified MICoMS 2017 illumination level, energy conservation of $80 \mathrm{~W}$ per light bulb will be obtained:

$$
\begin{aligned}
W_{\text {Konsv-SS }} & =80 \mathrm{~W} \times \text { number of poles } \times 4,145 \mathrm{~h} \\
& =80 \mathrm{~W} \times 9,565 \text { poles } \times 4,145 \mathrm{~h} \\
& =3.171 \mathrm{GWh}
\end{aligned}
$$

\section{8}

3.6. The effect of efficacy on $\mathrm{CO}_{2}$ emission reduction

Effect of lamp efficacy on $\mathrm{CO}_{2}$ emission is shown in Table 7.

Table 7.

The effect of Efficacy on $\mathrm{CO}_{2}$ emission reduction

\begin{tabular}{lcc}
\hline Emission Factor $\left(\mathrm{KgCO}_{2} / \mathrm{kWh}\right)$ & Energy conservation $(\mathrm{GWh})$ & $\mathrm{CO} 2$ emission reduction $\left(\mathrm{kTon} \mathrm{CO}_{2}\right)$ \\
\hline 1.14 & 1.189 & 1.355 \\
& 3.171 & 3.614
\end{tabular}

\section{Conclusion and recomendation}

Energy conservation is the act of maintaining the energy by reducing energy consumption or replacing energy sources to obtain the same benefits. In this paper, energy conservation obtained by replacing conventional energy sources with solar cells for the increased length of national street lighting is $3.171 \mathrm{GW}$ h in a year, and reduced carbon emission by $3.614 \mathrm{kTon} \mathrm{CO}_{2}$ are studied.

Solar cell technology is a fast growing technology. However, for the utilization of solar cells, the investment cost required must be taken into account (Elaydi et al., 2012).

In general, the public health can be viewed from a clean air environment. People living in rural areas tend to be healthier than people who live in urban areas. Air cleanliness is one of the important factors in human health (Fredrich et al., 2010), which can be determined in the form of a health index.

\section{References}

Biswas, B., Mukherjee, S. and Ghosh, A. (2013), "Conservation of Energi: A Case Study on Energi Conservation in Campus Lighting in an Institution". International Journal of Modern Engineering Research, Vol. 3, No. 4, pp. 1939-1941.

Boykoff, M.T., Frame, D. and Randalls, S. (2010). "Discursiv Stability Meets Climate Instability: A Critical Exploration of the Concept of Climate Stabilization in Contemporary Climate Policy". Global Environmental Change Human and Policy Dimension, Vol. 20, No. 1, pp. 53-64.

Dhingra, A. and Singh, T. (2009). "Energy Efficient Lighting: A way to Conserve Energy". International Journal of Energy, Vol. 3, No. 1, pp. 630-639.

Escolar, A.G., Martinez, A.C., Pulido, J.M.G., Martinez, J.M.G., Stapic, Z. and Merodio, J.A.M. (2015). “A Sutdy to Improve the Quality of Street Ligting in Spain”. Energy, Vol. 8, pp. 976-994.

Elaydi, H., Ibrik, I. and Koudary, E. (2012). "Conservation and Management of Electrical Energy in Gaza Strip Using Low Cost Investment”. International Journal of Engineering Research and Application, Vol. 2, No. 4, pp. 1152-1157.

Fredrich, K., Yunju, L., Yufang, S., Timn, T. and Andreas, W. (2010). “Greenhouse Gas Emissions from Nitrogen Fertilizer Use in China”. Environmental Science and Policy, , Vol. 13, No. 8, pp. 688-694. 
Khan, I. and Halder P.K. (2016). "Electrical Energy Conservation through Human Behavior Change : Perspective in Bangladesh”. International Journal of Renewable Energy Research, Vol. 6, No. 1, pp. 43-52.

Marcova, D., Platikanov, S., Konstantinoff, M. and Tsanov, P. (2011). "Opportunities for Using Renewable Energy Sources in Bulgaria”. Contemporary Materials (Renewable Energy Sources), II-2, UDK 620.91/.92:551.55(497.2). DOI: 10.5767/anurs. cmat.110202.en.178M

McVeigh, J.C. (1983). Sun Power, an Introduction to the Applications of Solar Energy. Pergamon Press.

Mohamed, A. and Mohamed, T.K. (2009). "A Review of Elektrical Management Techniques Supply and Consumer Side (Industries)”. Journal of Energy Southern Africa, Vol. 20, No. 3, pp. 14-21.

Padmini, V. (2014). "Conservation of Electrical Energy on SET-JU Campus through Auditing and Optimal Alternative Techniques". International Journal of Renewable Energy and Environmental Engineering, Vol. 02, No. 2, pp. 64-70.

\section{Corresponding author}

Janter can be contacted at janter_mh@yahoo.com 